\title{
Talking about Overseas Translation and Spread of Chinese Modern and Contemporary Literature
}

\author{
Youneng Yang ${ }^{1, \text { a }}$ \\ ${ }^{1}$ polytechic institute, Jiangxi Science and Technology Normal University, \\ Nanchang 3300108, China; \\ ayangyounengligong@163.com
}

Keywords: Chinese Modern and Contemporary Literature, Overseas Translation, Spread.

\begin{abstract}
Overseas translation and communication of Chinese modern and contemporary literature is an absolutely necessary component of Chinese culture "Going out" strategy. This paper first analyzes the present situation and existing problems of Chinese modern and contemporary literature, then discuss the reasons. At last, some pertinent countermeasures have been proposed in this paper. These countermeasures includes: Persisting in combining nationality with world and strengthening the study of the overseas recipient environment, etc.
\end{abstract}

\section{Introduction}

The overseas translation of the Chinese modern and contemporary literature should let Chinese good modern and contemporary literature go out of the country, to the world. In recent years, the "Going out" strategy of the Chinese culture has been highlighted as a national strategy. Seventeenth Party Central Committee clearly stated that letting Chinese culture walk up to the world. The Chinese Government pays high attention to Chinese culture than ever.

Chinese literature is a body carrying Chinese culture. Academic researchers had analyzed and inspected the overseas translation of Chinese modern and contemporary literature. GEN-Qing had inspected the situation of Chinese modern and contemporary literature in 2010 [1]. ZHEN-Yue had studied the translation of Chinese modern and contemporary literature in 2012 [2]. Pro. Bonnie S. McDougall at the University of Edinburgh had pointed out existing problems and modes of oversea publishing of Chinese literature.

These researches reached the same conclusions that the overseas translation of Chinese modern and contemporary literature were in trouble. The "Going-out" progress of Chinese modern and contemporary was relatively slow. The pure subjective solution made it hard for overseas readers to accept the Chinese modern and contemporary literature. It also made it impossible for Chinese modern and contemporary literatures to enter foreign spreading channel. There are some differences between Chinese culture and overseas culture. Cold mentality and power politics have a negative influence on construction and spreading of Chinese culture abroad. The translation and publishing of Chinese modern and contemporary literature not only involve translation itself, but also have close relations with spread context, accepting context and western social culture. As one of the most important parts of Chinese culture, the overseas translation of Chinese modern and contemporary literature has some problems [3]. What is the reasoning behind this? Should we push Chinese modern and contemporary literature to the world? This paper will analyze and explore the problem of overseas translation and spread of Chinese modern and contemporary literature.

\section{The Status of Overseas Translation and Spread of Chinese Modern and Contemporary Literature.}

The state institutions pay a leading role on overseas translation and publishing of Chinese modern and contemporary literature on the mainland. In 1995, YE Jun-jian just returned from abroad, and started "the Chinese Literature". The journal aimed to recommend good Chinese modern and contemporary 
literature to world, show new China face to the world. He and his colleagues undertook a large number of translation works. The "the Chinese Literature" became an important window of Chinese literature to see the world. In 1981, CIPG came out "Panda Books", and it faced directly Chinese literature and culture, especially Chinese modern and contemporary literature. But the books did not reach the expected effects. Except for receiving part of readers' like, most readers didn't cause such a strong backlash [4,5]. Chinese literature press established in 1987, focused on publishing "Panda Books" and "Chinese literature". But by the end of 2000, the Chinese literature press was already in trouble and was repealed. So the "Chinese literature" was suspended, and the "Panda Books" was almost stopped publishing. Although the Foreign Languages Press has taken over the publishing of the "Panda Books", it didn't go on to publish Chinese literature. In 2009, china took part in Frankfurt Book Fair as a main guest country. But these "Panda Books" were all re-publishing books of editions of "Panda Books". It really shows that overseas translation of the Chinese modern and contemporary literature suffered many setbacks.

In addition, another front of the Chinese modern and contemporary literature was "Renditions" from Hong kong. The English-language publication was established by translation research center of the Chinese University of Hong Kong. It was intended to introduce the Chinese culture in English to the western readers. Some famous celebrities (like Q.GAO, K.Y.GAO and H.Y, KONG) were in chief of "Renditions". The press had already successively some works of contemporary Chinese writers, most of these translators were foreign-born [6]. It achieved a better at broad.

With the translation of foreigners expertizes were a good publishing mode of overseas translation of Chinese modern and contemporary literature. Some foreigners expertizes were actively engaged in the translation of Chinese modern and contemporary literature, such as Howard Goldblatt, Michael Berry, Julia Lovell and Bonnie McDougall, etc. Because of some foreigners expertizes' efforts, some good Chinese modern and contemporary literature works received apparent achievement. Howard Goldblatt was called chief translators of Chinese modern and contemporary literature. He had translated a lot of Chinese writers' works. He made important contribution to the translation of Chinese modern and contemporary literature.

From output of Chinese literature copyright, the overseas translation of Chinese modern and contemporary literature was underdogs. The overseas translation of Chinese modern and contemporary literature lacked of a certain number readers, and didn't have much effect at broad. From the performance of international cultural market, Chinese modern and contemporary works were underdogs. Market coverage of overseas translation of Chinese modern and contemporary works was limit [7]. Most of those were heading for South Korea, Japan and Southeast Asian Nations, which shared in the small percentage. There was serious unbalance between input and output Chinese literature. Recently years, most of writers were foreigners. The overseas translation of Chinese and contemporary literature work has been basically gone to world market. There were statistics shows that China's press purchased 3932 books, but American press only purchased 16 Chinese literature works. America published 348 foreign literature works in 2009, among them only had 8 Chinese literature works.

The overseas translation works of Chinese modern and contemporary literature were the brink position of world literature. The impact of the Chinese modern and contemporary literature works is limited. These readers were concentrated in some Sinologists.

\section{The Cause Analysis of the Existing Problems of Overseas Translation and Spread}

After analyzing the status situation and existing problem of overseas translation and spread of Chinese modern and contemporary literature works, we found that there was some root problems. The awareness and thoughts of problems would not only help us correctly understand the facing troubles of overseas translation works of Chinese modern and contemporary literature, but also improve states of Chinese literature, and enhance popularity of the "Going-out" strategy. In addition, it was also build cultural self-confidence of Chinese nation, and motivate sustainable development to practice better. 
The Prejudices of Western Readers. The western culture was strong culture in the world today, which played a central role. Chinese culture was a weak culture, and which was on the periphery. The western culture globalization occupied leading position on literature and aesthetic value, which let western readers generate entrenched prejudices for Chinese culture. Western media and cultural generally believe that the Chinese literature entrenched materials of china. It is "boring sermons". Some western readers also think that the Chinese literature was not only the political fodder, but also lack of literature value, and it is difficult to attach readers. Some experts even believe that the materials of the Chinese modern and contemporary literature works were draw from enclosed country and political persecution. The traditional western prejudice prevented western readers from understanding Chinese culture for a long time. The prejudice distorted people's understanding about the Chinese modern and contemporary literature works. This would produce much negative influence on the understanding and spread of Chinese modern and contemporary literature. The authenticity and completeness of Chinese modern and contemporary literature cannot be reflected objectively.

The Error of Spread Decisions. The related organization cannot fix position during the publishing process of overseas translation and spread of overseas of Chinese modern and contemporary literature. Bonnie McDougall was familiar with extension system of "Chinese Literature" and "Panda Books", and he points out that policy makers have trouble understanding foreign language, and pay less attention to the actual readers of literature translation, and pay more attention to professional readers (eg. Publisher, editor, critics and scholar). Ideology pays an important role on literature selection and translation, so it makes overseas translation and spread of Chinese modern and contemporary literature produce strong subjective feeling. It has strong propaganda meaning. This weakens the aesthetic value of overseas translation of Chinese modern and contemporary literature, and reduces the appeal of western readers.

In addition, publishing channel will also seriously restrict the overseas spread of Chinese modern and contemporary literature. It is difficult that Chinese modern and contemporary literature works are published by western leading press. Many overseas translations of Chinese modern and contemporary literature are published by the academic press. It is difficult for this mode to attach many readers.

\section{The Related Countermeasures of Overseas Translation and Spread of Chinese Modern and Contemporary Literature}

The Selection should be Persist in Nationality with World. "What is of national is of international”. The national style should be linked with human worth, universal feelings and world culture character. In Mo Yan's novel, it describes the contemporary Chinese society in accordance with his hometown, and shows the spiritual connotation of Chinese tradition. In addition, his works are full of international flavor. In a word, most of Mo Yan's novels not only have national and native elements, but also contains the expression of western modern literature. That is how he won the Novel prize.

Strengthening the Study of the Overseas Recipient Environment. The Chinese people actively translated the western culture one hundred years ago. The western culture was introduced to china at that time. But the west actively translated Chinese culture only over 20 years. This made many Chinese people understand the western culture, but the western readers known very little about Chinese culture. At that time, western readers were unwilling to accept Chinese culture. So many foreign readers have gradually given up on understand the Chinese culture. At his stage, the overseas translation and spreading of Chinese modern and contemporary literature need change that. Translators should adopt some methods to solve the problems. So that foreign readers can understand and accept the Chinese literature works better.

In addition, an important question is that it is difficult for a common foreigner to master and understand the Chinese culture. The situation will still exist, at least for a long time. This will also restrict the foreign readers to understand the Chinese culture. So we should pay more attention to 
cultivate foreign reader, and make for more people to understand the Chinese modern and contemporary literature.

\section{Summary}

Chinese modern and contemporary literature is an important part of world literature, which shows the reals life of the ordinary Chinese people and "world-soul" the by its own unique $\mathrm{f}$ literary discourse. The unique literary discourse need to go to world. In view of the existing various problems of overseas translation and spread of Chinese modern and contemporary literature, we should be analyze the reasons, and find out feasible countermeasures for development of Chinese modern and contemporary literature. In pushing through the overseas translation and spread of Chinese modern and contemporary literature, we should hold an open and dialogue of attitude, and remove ideology impact. We should study Chinese literature with more literature value and keep cultural self-confidence. Only by combining Chinese literature with western literature, can the Chinese literature go to the international truly.

\section{References}

[1] Q.GEN. Literature Translation of Chinese Literature "Go to World"--- Study of Chinese Literature of "Panda Books”, Shanghai: Shanghai Foreign Studies University, 5(2010): 121-124.

[2] Heller, S. A Translation Boom for Chinese Fiction, Chronicle of Higher Education, 24 (2010): 25-28.

[3] B.H.SANG. In Views of Chinese Novel of an Ordinary American: Talking about English-Chinese Novel, the Chinese Writers'Association, 12(2010):138-140.

[4] Lovell. J. Great Leap Forward, The Guardian, 25(2009): 11-13.

[5] X.G.MENG. Chinese Literature Entered the world, Chinese Books Business, 10(2015):109-112.

[6] Medougall. B. Literary Translation: The Pleasure Principle, Chinese Translators Journal,12(2007): 25-27.

[7] W.G. CAO, Overseas Translation and Communication of Chinese Modern and Contemporary Literature, Journal of Hubei University of Education , 32(2013):118-120. 